\title{
Sawing Capacities in the Czech Republic
}

\section{Pilanski kapaciteti u Republici Češkoj}

\author{
Professional paper • Stručni rad \\ Received-prispjelo: 4. 11. 2010. \\ Accepted-prihvaćeno: 27. 4. 2011. \\ UDK: $630 * 832.1 ; 674.093$ \\ doi:10.5552/drind.2011.1037
}

\begin{abstract}
The author recapitulates the development of the sawmilling in the Czech Republic after the World War II, and describes the major investments in the nineties of the past century and since 2000 until today. The paper shows the main timber-processing plants bordering with the surrounding countries, which fundamentally affect the exports of the logs from the Czech Republic. In the next part the author presents the summary of roundwood cutting in the period 1991 to 2009, and describes the creation of the database of the important sawmill plants in the Czech Republic. These plants are then divided into 7 groups according to the size, and their list is available in Table 2. Subsequently the paper provides a general division of the sawmill plants into individual groups according to the used technology. Then the author compares the sawmill sawing of more than 50,000 $\mathrm{m}^{3}$ of logs per year in the Czech Republic, Switzerland, Germany and Austria. The conclusion of the paper deals with the potential future development of the sawmill capacities in the Czech Republic and with the level of their expected concentration.
\end{abstract}

Key words: Czech sawmilling, sawmill production, sawing capacities, log cutting technology

SAŽETAK • Autor prikazuje i analizira razvoj pilanarstva u Republici Češkoj nakon Drugoga svjetskog rata te opisuje kapitalne investicije 1990-ih godina i one od 2000. godine do danas. U radu se prikazuju glavna postrojenja za obradu drva smještena u blizini granice sa susjednim zemljama, koja znatno utječu na izvoz trupaca iz Republike Češke. Ujednom dijelu rada autor daje sažeti pregled obrade oblog drva u razdoblju od 1991. do 2009. godine i opisuje stvaranje baze podataka o važnim pilanama u Republici Češkoj. Pilane su prema veličini podijeljene u sedam skupina, a njihov prikaz dan je u tablici 2. Nakon toga u radu se može pronaći općenita podjela pilana u skupine prema primijenjenoj tehnologiji obrade trupaca. Autor zatim uspoređuje postrojenja koja propiljuju više od $50000 \mathrm{~m}^{3}$ trupaca u godini u Republici Čě̌koj, Švicarskoj, Njemačkoj i Austriji. Zaključno, u radu se navode mogućnosti razvoja pilanskih kapaciteta u Republici Češkoj i predviđa stupanj njihova okrupnjavanja.

Ključne riječi: češko pilanarstvo, pilanska proizvodnja, pilanski kapaciteti, tehnologija obrade drva

\section{INTRODUCTION \\ 1. UVOD}

After 1948, due to the nationalization of industry in our country, the sawmill production was also separated from the development in the Western Europe. No big sawmill plants larger than $200,000 \mathrm{~m}^{3}$ of logs cut per year were established for a long time in the Czech Republic, and most of the production was aimed at the sawmill cutting ranging between 20,000 and $50,000 \mathrm{~m}^{3}$ of logs per year. The first steps toward the bulk production in this field were made in the seventies of the $20^{\text {th }}$ century (Ždírec, Vrbno pod Pradědem, Volary, Borohrádek); however, there was no massive onset of new sawmill technologies. A classic frame-saw technology with a very low level of automation played a major role. Similar development was recorded in the eighties of the $20^{\text {th }}$ century, and it can be said that there was no development of the sawmill capacities through several generations, as used to be the case in western countries.

\footnotetext{
${ }^{1}$ The author is the Chairman of the Association of Woodworking Plants in the Czech Republic, Polička, Czech Republic.

${ }^{1}$ Autor je predsjednik Udruženja drvoprerađivačkih poduzeća u Republici Češkoj, Polička, Republika Češka.
} 
In 1991, the first small sawmill plants were transferred into private hands due to a small wave of privatization and they started developing gradually. Nonetheless, the majority of the mid-sized sawmill plants remained within the associations of the former large woodworking plants, which were organized on a regional level and controlled centrally. Then within the frame of these associations, such plants were transferred into private ownerships through a large privatization.

Thereafter, the first entries of the foreign capital into this field were recorded in the independent Czech Republic. This was an investment project of the company named Schweighofer into the sawmill plants in Ždírec, and later in Planá u Mariánských Lázní (Pražan and Př́ḱkaský, 2007).

The first half of the nineties of the $20^{\text {th }}$ century was the time of a serious chaos, and the then-unknown phenomenon of insolvency. This naturally brought in considerable problems in transformation of the forest economy for the newly founded corporations, which made the base of the timber trade.

Not sooner than after 2000, other investments into timber processing were made to enhance further development of the later bankrupt sawmill plant in Ptení - a company of Javořice a.s., and especially later via the largest investment into the sawmill plant in Paskov by an Austrian company of Mayr Melnhof.

Within the last 5 years, the situation has changed considerably in Central Europe, and the vicinity of our borders received new investments involving the resources of large timber logs cutting held by the following companies:

- Klausner Holz Sachsen in Kodersdorf (northern border with Germany)

- Holzindustrie Maresch in Retz (near the southern border with Austria)

- Ludwig Ziegler in Betzenmühle (near the western border with Germany)

In the Czech Republic this type of development has been simultaneously accompanied by an important investment project of Javořice a.s. in Ptení, by a further increase of the sawmill capacity in Ždírec (Stora Enso Timber), and by a new, very intensive construction of the sawmill in Chánovice (near Horažd'ovice) rendered by a German company of Haas Fertigbau.
All of these investment projects do naturally create a certain tension on the market of coniferous timber logs, and certainly because of that, some of the projects have never been implemented (Protivín, Northern Bohemia, Etc.). However, during the development of large sawmills, the sawmill plants of various capacities, being established for many years, have become subject to eradication (e.g. Šumperk, Vrbno, Volary, Jirkov, Mariánské Lázně, Vrchlabí, Letohrad, Jihlava, Etc.). Nevertheless, in the same period many - especially very small - sawmill plants were established with an insignificant total timber production (Pražan, Příkaský: 2007). The newest development also caused the closure of the first large-scale sawmill plant in the Czech Republic (Javořice a.s. in Ptení) in the beginning of 2009. On the other hand, a new sawmill plant was built in Cáslav $\left(260,000 \mathrm{~m}^{3}\right.$ of logs cut per year).

\section{SAWING OF LOGS}

2. PILJENJE TRUPACA

Today the sawing of logs and production of timber may be determined from the sources of the Ministry of Agriculture of the Czech Republic stated in the report on the status of the forests and forest economy in the Czech Republic.

A summary of these data is presented in Table 1 below.

According to the information of the Ministry of Agriculture of the Czech Republic, the above data were determined based on the total roundwood exploitation in the Czech Republic, out of which the exports of the logs are deducted and to which the imports of the logs are added. Based on the ratio of the fiber, fuel and roundwood, the cuts are calculated additionally. According to the author, the amount of sawn logs in 2010 may be estimated to approximately $7,000,000 \mathrm{~m}^{3}$.

\section{IMPORTANT SAWMILL PLANTS}

\section{VAŽNA PILANSKA POSTROJENJA}

In autumn 2009, the management of the Association of Woodworking Plants in the Czech Republic (hereinafter referred to as "SDP"), which represents

Table 1 Sawing of logs and production of timber in thousands of cubic meters $\left(\mathrm{m}^{3}\right)$ (Ministry of Agriculture of the Czech Republic: 1991 - 2009)

Tablica 1. Piljenje trupaca i proizvodnja piljenica iskazani u tisućama metara kubičnih $\left(\mathrm{m}^{3}\right)$ (Ministarstvo poljoprivrede Češke Republike, 1991 - 2009)

\begin{tabular}{|c|c|c|c|c|c|}
\hline $\begin{array}{c}\text { Year } \\
\text { Godina }\end{array}$ & $\begin{array}{c}\text { Sawing of logs } \\
\text { Piljenje trupaca }\end{array}$ & $\begin{array}{c}\text { Timber production } \\
\text { Proizvodnja piljenica }\end{array}$ & $\begin{array}{c}\text { Year } \\
\text { Godina }\end{array}$ & $\begin{array}{c}\text { Sawing of logs } \\
\text { Piljenje trupaca }\end{array}$ & $\begin{array}{c}\text { Timber production } \\
\text { Proizvodnja piljenica }\end{array}$ \\
\hline 1991 & 3,850 & 2,400 & 2001 & 6,600 & 3,889 \\
\hline 1992 & 3,850 & 2,400 & 2002 & 6,441 & 3,800 \\
\hline 1993 & 4,500 & 2,800 & 2003 & 6,500 & 3,805 \\
\hline 1994 & 5,600 & 3,500 & 2004 & 6,800 & 3,940 \\
\hline 1995 & 6,000 & 3,800 & 2005 & 6,900 & 4,003 \\
\hline 1996 & 6,200 & 3,900 & 2006 & 8,650 & 5,080 \\
\hline 1997 & 5,784 & 3,393 & 2007 & 8,700 & 5,454 \\
\hline 1998 & 6,250 & 3,420 & 2008 & 7,650 & 4,636 \\
\hline 1999 & 6,580 & 3,577 & 2009 & 6,700 & 4,048 \\
\hline 2000 & 7,170 & 4,106 & & & \\
\hline
\end{tabular}


Table 2 Division of the Czech Republic sawmill plants processing coniferous and leafy timber according to the amount of logs sawn in 2009 (active as of December 31, 2009)

Tablica 2. Podjela čeških pilana koje prerađuju četinjače i listače prema količini propiljenih trupaca u 2009. godini (podaci od 31. prosinca 2009)

\begin{tabular}{|c|c|c|c|c|c|c|c|}
\hline $\begin{array}{c}\text { Sequen- } \\
\text { ce num- } \\
\text { ber } \\
\text { Broj } \\
\text { skupine }\end{array}$ & $\begin{array}{c}\text { Size group in } \mathbf{m}^{3} \\
\text { of logs sawn per } \\
\text { year / Veličina } \\
\text { skupine iskazana } \\
\text { količinom } \\
\text { propiljenih } \\
\text { trupaca }\end{array}$ & $\begin{array}{c}\text { Group title } \\
\text { Naziv skupine }\end{array}$ & $\begin{array}{l}\text { Number of } \\
\text { sawmill } \\
\text { plants in } \\
\text { the group } \\
\text { Broj pilana } \\
\text { u skupini }\end{array}$ & $\begin{array}{c}\text { Total sawing } \\
\text { of logs in } \\
\text { thousands of } \\
\mathbf{m}^{3} / \text { Ukupni } \\
\text { prorez } u \\
\text { tisućama } m^{3}\end{array}$ & $\begin{array}{l}\text { Percent of } \\
\text { sawing, \% } \\
\text { Udjel } u \\
\text { ukupnom } \\
\text { prorezu } \\
\text { svih } \\
\text { pilana,\% }\end{array}$ & $\begin{array}{c}\text { Percent of } \\
\text { the total } \\
\text { number, \% } \\
\text { Udjel } u \\
\text { ukupnom } \\
\text { broju } \\
\text { pilana, \% }\end{array}$ & $\begin{array}{c}\text { Average log } \\
\text { sawing of the } \\
\text { plant in thou- } \\
\text { sands of } \mathbf{~ m}^{3} \text { per } \\
\text { year / Prosječni } \\
\text { godišnji prorez } \\
\text { pilane u tisućama } \\
m^{3}\end{array}$ \\
\hline 1 & 200,000 plus & $\begin{array}{l}\text { super-large } \\
\text { sawmill plants } \\
\text { supervelike pilane }\end{array}$ & 4 & 2,850 & 40.1 & 0.4 & 712 \\
\hline 2 & $50,000-200,000$ & $\begin{array}{l}\text { large sawmill } \\
\text { plants } \\
\text { velike pilane }\end{array}$ & 12 & 956 & 13.5 & 1.1 & 80 \\
\hline 3 & $20,000-49,999$ & $\begin{array}{l}\text { large-medium } \\
\text { sawmill plants } \\
\text { umjereno velike } \\
\text { pilane }\end{array}$ & 35 & 1,005 & 14.1 & 3.3 & 29 \\
\hline 4 & $10,000-19,999$ & $\begin{array}{l}\text { mid-sized sawmill } \\
\text { plants / pilane } \\
\text { srednje veličine }\end{array}$ & 58 & 747 & 10,5 & 5.4 & 13 \\
\hline 5 & $5,000-9,999$ & $\begin{array}{l}\text { small sawmill } \\
\text { plants of category } \\
2 \text { / male pilane } 2 . \\
\text { kategorije } \\
\end{array}$ & 88 & 565 & 8.0 & 8.3 & 6.4 \\
\hline 6 & $2,500-4,999$ & $\begin{array}{l}\text { small sawmill } \\
\text { plants of category } \\
1 \text { / male pilane } 1 . \\
\text { kategorije }\end{array}$ & $37+80 *$ & $127+250^{*}$ & 5.3 & 11.0 & 3.2 \\
\hline 7 & $0-2,499$ & $\begin{array}{l}\text { very small } \\
\text { sawmill plants } \\
\text { vrlo male pilane }\end{array}$ & $750^{*}$ & $600^{*}$ & 8.5 & 70.5 & 0.8 \\
\hline & Total / Ukupno & & $1,064 *$ & $7,100 * *$ & 100 & 100 & 6.7 \\
\hline
\end{tabular}

* estimate of the amount and roundwood consumption of the small and very small sawmill plants not included in the list of the sawmill plants and not detected by the research conducted by SDP / procjenjuje količinu potrošnje oblog drva malih $i$ vrlo malih postrojenja koja nisu uključena u listu pilanskih postrojenja i nisu uključena u istraživanja koja provodi SDP

** assumed sawing of all plants in the Czech Republic derived from the report on the status of the forests (Ministry of Agriculture of the Czech Republic: 2008) and from the percentage of drop in the sawing between 2008 and 2009 (found from the research conducted by SDP) / pretpostavlja količinu proreza svih pilana u Češkoj Republici prema izvješću o stanju šuma (Ministarstvo poljoprivrede Češke Republike, 2008) i prema postotku smanjenja proreza između 2008. i 2009. godine (utemeljeno na istraživanjima koja provodi SDP)

primarily the small and mid-sized plants, organized an extensive opinion poll among its member firms with the objective to find their current cutting capacity during 2008 and 2009, their revenues, and their total number of employees.

Based on the verified data on the annual sawing of logs in the sawmill plants, decision was made to create a nationwide list of important sawmill plants in order to allow monitoring of the participation of the SDP firms in the total sawing in the Czech Republic. For the purpose of this task, a team was assembled, which verified and detected the locations and outputs of the larger sawmill plants in the Czech Republic from December 2009 to February 2010. The guidance was based on the documentation provided by the management of Terra Magazine, on the original summary of the sawmill plant activities, and on the private database of the sawmill plants created by certain professionals in this field in the Czech Republic. Most of the plants were contacted by telephone, and the sawing data were provided by the owners or responsible employees. For the purpose of comparison, the data from 2008 were also requested (if known and available). With regard to the practical impossibility to find the sawing data from the small and very small plants, the minimum borderline was determined as $2,500 \mathrm{~m}^{3}$ of $\log$ sawing per year. The list was created successfully and contained more than 230 sawmill plants.

Based on the analysis of this list, the sawmill plants were divided into size groups according to the amount of the log sawing. In order to complete the quantity calculation of all sawmill plants, a professional estimate was made of the quantity of the small and very small sawmill plants according to the experiences from the regions of the Czech Republic, and according to the detected numbers of the sawmill plants in Germany, Austria and Switzerland. The mobile sawmill plants operating during a year at various locations were not accounted for.

The division of all sawmill plants is shown in Table 2 . 
Table 3 Comparison of the amount and of sawmill plants in Central Europe processing more than 50,000 $\mathrm{m}^{3}$ roundwood per year (Holzkurier 2010a, 2010b, 2009)

Tablica 3. Usporedba veličine proreza u pilanama Središnje Europe koje propiljuju više od $50000 \mathrm{~m}^{3} \mathrm{u}$ godini

\begin{tabular}{|c|c|c|c|c|c|}
\hline $\begin{array}{l}\text { Country } \\
\text { Država }\end{array}$ & \begin{tabular}{|c|}
$\begin{array}{c}\text { Number } \\
\text { of firms }\end{array}$ \\
Broj \\
tvrtki
\end{tabular} & $\begin{array}{c}\text { Number of sawmill } \\
\text { plants (locations) } \\
\text { Broj lokacija } \\
\text { pilanskih postrojenja }\end{array}$ & $\begin{array}{c}\text { Annual consumption } \\
\text { of roundwood in } \\
\text { thousands of } \mathbf{m}^{3} \mathbf{2 0 0 9} \\
\text { Godišnja potrošnja } \\
\text { trupaca u tisućama } \mathrm{m}^{3}\end{array}$ & \begin{tabular}{|c|} 
Plan for 2010 \\
in thousands of \\
$\mathbf{m}^{3} /$ Plan $z a$ \\
$2010 . u$ \\
tisućama $\mathrm{m}^{3}$ \\
\end{tabular} & $\begin{array}{c}\text { \% of sawing from } \\
\text { the country total } \\
\text { in } 2009 \text { / Postotak } \\
\text { proreza u ukupnom } \\
\text { prorezu } 2009 .\end{array}$ \\
\hline Austria / Austrija & 37 & 55 & 12,481 & 12,663 & 95 \\
\hline Germany / Njemačka & 75 & 89 & 28,151 & 28,435 & 77 \\
\hline Switzerland / Švicarska & 6 & 7 & 888 & 950 & 40 \\
\hline $\begin{array}{l}\text { Czech Republic } \\
\text { Republika Češka }\end{array}$ & 15 & 16 & 3,806 & unknown & 54 \\
\hline
\end{tabular}

4 DIVISION OF SAWMILL PLANTS ACCORDING TO LOG CUTTING TECHNOLOGY

4. PODJELA PILANA PREMA PRIMIJENJENOJ TEHNOLOGIJI

The division of sawmill plants in the Czech Republic was performed according to the amount of cubic meters $\left(\mathrm{m}^{3}\right)$ of logs cut per year to fit into groups, which also partially correspond to the technological advancement of individual sawmill plants. (Friess, 2006).

Generally, the individual cutting capacity groups could be divided as follows:

Groups according to the annual sawing of logs in cubic meters $\left(\mathrm{m}^{3}\right)$

$0-5,000$ :

very small sawmill plants with no mechanical equipment; very small sawmill plants with frame saws without sawmill ground floors; or simple band-saw plants;

2,500-5,000:

small sawmill plants with no mechanical equipment; or small sawmill plants with primitive mechanical equipment with no electric drive;

5,000-10,000:

smaller sawmill plants mostly with single-frame saws; or exceptionally band-saw plants with several individual saws;

$10,000-20,000$ :

mid-sized sawmill plants with single-frame saws but mostly dual-frame saws; moderately mechanical midsize sawmill plants with electric-drive conveyors, mostly working in one shift; or log band-saw plants combined with trimming saw or resaw;

20,000-50,000:

large-medium sawmill plants with dual-frame gang circular saws, automated with mechanical equipment, mostly working in two shifts; or in some cases, the frame-saw plants, also combined with lines for cutting small diameter roundwood;

$50,000-200,000$ :

large sawmill plants with aggregate technologies, automated, working in two or three shifts; or in some cases aggregate lines with a line of frame-saws for cutting thick logs;

200,000 plus:

super-large sawmill plants of more than 1,000,000 $\mathrm{m}^{3}$ of logs cut per year, with very powerful aggregate technologies, fully automated, working in three or four shifts - usually these plants feature more than one aggregate line, but there are also single-line operations with such high output achieved by means of continuous production.

\section{COMPARISON OF LARGE SAWMILLS IN THE CZECH REPUBLIC AND} SURROUNDING COUNTRIES

\section{USPOREDBA VELIKH PILANA U ČEŠKOJ I OBLIŽNJIM DRŽAVAMA}

The creation of the list of sawmill plants in the Czech Republic and detection of their sawing in 2009 allowed the comparison of large and super-large sawmill plants in the Czech Republic with certain countries that feature sawmill plants sawing more than $50,000 \mathrm{~m}^{3}$ of roundwood per year - this comparison is shown in Table 3.

\section{POTENTIAL FUTURE DEVELOPMENT OF CONCENTRATION OF CAPACITIES IN THE} CZECH REPUBLIC

6. MOGUĆNOSTI RAZVOJA I OKRUPNJAVANJA PILANSKIH KAPACITETA U REPUBLICI ČEŠKOJ

As seen in Table 3, the Czech Republic has not yet reached such concentration of the sawing in large sawmill plants as for example Austria and Germany, but the Czech Republic has already superseded the plants in Switzerland. The total rapid increase of the sawing in the Czech Republic is not usually the order of the day because the surrounding countries rather import the timber logs from the Czech Republic than export, and the resources in the Czech Republic are continuously exploited to their maximum at permanently sustainable output.

Due to the above reasons, it may be said that the establishment of the additional large sawmill capacities with more than $500,000 \mathrm{~m}^{3}$ of logs processed per year may not be expected, and that otherwise the large shifts in the sawing may happen in the amounts of $20,000-100,000 \mathrm{~m}^{3}$ with a shift to the higher level of processing at the expense of the small ones. Generally, it may be concluded that approximately $50 \%$ of all coniferous roundwood in the Czech Republic is processed by small and mid-sized sawmill plants, so they still happen to be the basic processors of this raw material. 
We may assume that the additional concentration would be coming at a slow rate, not as fast as hitherto, and that the levels of, for instance, Germany may be reached within 10 to 20 years. The gradual modernization and increase in work productivity will cause the improvements in sawing of certain mid-sized sawmill plants; however, due to the long-term insecure situation in purchasing raw materials, such modernization would not be happening so often, and several of such plants may again cease to exist because of high indebtedness created by investments into the process of modernization.

\section{REFERENCES}

\section{LITERATURA}

1. Friess, F., 2006: Corporation size and strategy in sawmill industry (Czech), ČZU Praha 2006, pp12-17.

2. Pražan, P.; Př́kaský, F., 2007: The position of the small and medium size sawmill enterprises in the Czech Republic (Czech), in Lesnická práce (Journal of forest science and practice) 3/2007, 151-153.

3. *** Holzkurier, 2009: Größte Sägewerke Östereichs mit über 50000 FM Jahreseinschnitt-Produktion 2009/Plan 2010, Holzkurier Magazine 53/2009, Page 10, Dec 31, 2009.
4. *** Holzkurier, 2010a: Die Sägeindustrie Deutschland mit über 50000 FM Jahreseinschnitt 2009/2010, Holzkurier Magazine 05/2010, Pages 10-11, Feb 04, 2010.

5. *** Holzkurier, 2010b: Schweizer TOP-Sägewerke 2010 (Geselschafsberichte und Firmenangaben), Holzkurier Magazine 05/2010, Page 11, Feb 04, 2010.

6. *** Ministry of Agriculture of the Czech Republic, 19912009: Report on Forestry of the Czech Republic, Status as of Dec 31, 1999 to Dec 31, 2009-Ministry of Agriculture of the Czech Republic, Section of „Dřevozpracující průmysl“" (Woodworking Industry) - Roundwood and sawnwood production.

\section{Corresponding address:}

Ing. PETR PRAŽAN

Chairman of the Association of Woodworking Plants in the Czech Republic

Dřevozávod Pražan s.r.o.

T. Novákové 315

57201 Polička, CZECH REPUBLIC (EU)

e-mail: mail@drevozavod-prazan.cz 